\title{
STATE POLICY OF THE REPUBLIC OF UZBEKISTAN TO ENSURE THE INTERNATIONAL CONSENT AND TOLERANCE IN SOCIETY
}

\author{
Rakhbar Khamidovna Murtazaeva \\ Doctor of Historical Sciences (DSc), Professor, Department of "History of Uzbekistan" of National \\ University of Uzbekistan, Tashkent, Uzbekistan
}

Article DOI: https://doi.org/10.36713/epra4011

\begin{abstract}
The article, based on official documents, reveals the state policy in the field of interethnic relations in Uzbekistan at the present stage. The experience of Uzbekistan in maintaining stability in interethnic relations and friendship between representatives of more than 130 peoples living in the republic is shown, and a conclusion is drawn about the Uzbek model of interethnic harmony. It is also emphasized that in historically multi-ethnic Uzbekistan, tolerance is the basis of mutual understanding and harmony in society, the most important condition for finding compromises and overcoming conflicts. The article describes the problems and specific tasks in the field of interethnic relations that arose in the context of globalization, integration and migration.
\end{abstract}

KEY WORDS: Interethnic harmony, tolerance, the Uzbek model of interethnic harmony, interethnic tolerance, confrontation in information and cyberspace, educating young people in the spirit of tolerance.

\section{INTRODUCTION}

The state policy of Uzbekistan in the field of national relations (ethno politics) in the broad sense is an integral part and a specific aspect of politics in a multinational, multi-ethnic state. Being included in the general context of politics, it has a certain independence, and as such is capable of both accelerating and inhibiting the course of social, and therefore national development. Ethno politics in the narrow sense is a strategic course of government structures, political parties, social movements of multiethnic states in the national question, which is embodied in legislative acts, special programs and other relevant documents.

Democratic ethno politics is based on the following principles:

- Equal rights of ethnic groups, tolerance,

- Interethnic, interethnic harmony and

- The prohibition of any form of undemocratic solution to the national question (nationalism, racism, fascism, apartheid, segregation, deportation, forced migration, forced assimilation, etc.),

-Supporting minority rights to preserve ethnic identity and identity.
- A combination of ethno-national and national interests,

\section{METHODS}

As noted in the International Convention on the Elimination of All Forms of Racial Discrimination: "any theory of superiority based on racial difference is scientifically false, moral is reprehensible, and social is unfair and dangerous and that there can be no excuse for racial discrimination, where whatever: neither in theory nor in practice"[1].

Equality, consolidation, interaction, joint prosperity of all ethnic groups - these are the basic principles of ethno politics of the Republic of Uzbekistan.The Constitution and other legislative acts of the Republic (the Law "On the State Language", the Law "On Citizenship" and etc.) [2]. Also state: all citizens of the Republic of Uzbekistan, regardless of nationality, are equal; the state guarantees the legitimate rights and interests of all nationalities, discrimination of any nationality is prohibited, as well as actions aimed at undermining the cohesion of nationalities.

The Decree of the President of the Republic of Uzbekistan "On Approving the Concept of the State Policy of the Republic of Uzbekistan in the Field of 


\section{SJIF Impact Factor: 6.260| ISI I.F.Value:1.241| Journal DOI: 10.36713/epra2016

Interethnic Relations" emphasizes that "in modern conditions, representatives of more than 130 nations and nationalities living in the country, using the same rights and opportunities provided by the Constitution and laws of the Republic of Uzbekistan, work fruitfully in various sectors of the economy and social sphere, fields of science and culture, making a worthy contribution to the prosperity of the motherland and strengthening it independently minute, increasing the credibility and image of the country in the international arena" [3].

The state opposes national chauvinism and nationalism: each nation has the right to freely apply and develop its own language and culture, and has the right to preserve its own beliefs, traditions, rites, and customs. The Universal Declaration of Human Rights noted that "the recognition of the dignity inherent in all members of the human family, and their equal and inalienable rights, is the basis of freedom, justice and universal peace", "it is necessary to promote the development of friendly relations between peoples" [4].

\section{RESULTS AND DISCUSSIONS}

Large-scale social reforms in modern Uzbekistan requires the main thing - interested support, active the participation of the whole people, each citizen, regardless of their ethnicity, confessional, social tender unreliability. In this regard the problem of people's interest in their present and future. Most researchers and experts stability and favorable dynamics of the development of interethnic relations in our country are noted.

In realizing the ethno-cultural needs and interests of society, two areas that are organically linked to each other can be defined as the main and decisive goal. One of these areas is based on the strengthening of ethnic traditions, customs, the development of the national language, the ethnic characteristics of spirituality that serve today's national development, and the formation of an ethnically oriented worldview and thinking. The second direction is the emphasis on universal values and the achievement of world progress. Based on these ideas, principles and directions, it is necessary to educate young people and develop an understanding of her own interests and aspirations.

Uzbekistan compares favorably with other countries by stability in interethnic relations. With the acquisition of independence in Uzbekistan, a completely new socio-political situation arose in the development of interethnic relations. To ensure stability in our multinational country in difficult conditions of transition to market relations, the formation of a new Uzbek state, it was necessary from the very beginning to pursue a weighted national policy that does not infringe on the rights and interests of numerous ethnic minorities in the republic.

Uzbekistan is traditionally multinational, multi-ethnic. The history of the interaction of various ethnic groups dates back to ancient times. For centuries, Tajiks, Kazakhs, Kyrgyz, Turkmens, Karakalpaks, Bukhara Jews, Persians, Arabs, Uighurs, Dungans and etc. live next to the Uzbeks. For a long time, ethnic processes and interethnic relations in Uzbekistan are characterized by openness, friendliness, and good neighborliness. Most of the indigenous ethnic groups in the region are united by a deep household, linguistic, religious, ethno cultural affinity.

Ethnic mosaicism and cultural diversity are considered as the richest progressive potential, an influential lever for the construction of a new democratic rule of law and civil society, social justice and interethnic harmony. An analysis of the development trends of interethnic relations over 28 years of independence testifies to our country's own path in interethnic relations. It is based on centuriesold traditions of tolerance, mutual understanding, friendly and respectful attitude to other nations. Uzbekistan is proud that in the historical memory of our people and the state there are no shameful pages of manifestation of anti-Semitism, racism and other forms of arrogant and disrespectful attitude to another nation, to another people.

Own state policy in the field of interethnic relations, a civilized and humanistic approach to solving interethnic problems has led to stability in interethnic relations, favorably distinguishing Uzbekistan from other states. In today's conditions of independence, we can definitely conclude that the Uzbek model of interethnic harmony is being implemented in the republic.

At a new stage in the development of Uzbekistan, the President of the Republic of Uzbekistan, Sh. Mirziyoyev adopted a number of documents that further strengthen interethnic stability in the country.

Adoption and implementation of the Strategy of action in five priority areas of the development of the Republic of Uzbekistan in 2017-2021, the very time in which we live, the need to implement a balanced, mutually beneficial and constructive foreign policy aimed at strengthening the independence and sovereignty of the state, creating a security belt around the country, stability and good neighborliness, as well as further strengthening in the minds of the population, especially youth, humanistic values, maintaining and supporting an atmosphere of mutual agreement, respect and mutual assistance between different nationalities require raising to a new level of work carried out in this area. 


\section{SJIF Impact Factor: 6.260| ISI I.F.Value:1.241| Journal DOI: 10.36713/epra2016 ISSN: 2455-7838(Online) EPRA International Journal of Research and Development (IJRD)}

The decree of the President of the Republic of Uzbekistan Sh. Mirziyoyev "On measures to further improve interethnic relations and friendly relations with foreign countries" [5] is aimed at further ensuring stability, peace and harmony in society, strengthening the feeling of belonging to a large, united multinational family, comprehensive in the minds of citizens support and further development of the activity of national cultural centers and friendship societies, expansion of cultural and educational ties with foreign countries The creation of the Committee on Interethnic Relations and Friendly Relations with Foreign Countries under the Cabinet of Ministers of the Republic of Uzbekistan on the basis of the Republican International Cultural Center and the Council of Friendship Societies and Cultural and Educational Relations with Foreign Countries of Uzbekistan, with 138 national and cultural centers, 34 friendship societies with foreign countries.

The Committee is actively involved in solving the problems of the consistent implementation of state policy in the field of ensuring interethnic harmony and tolerance in society, a broad explanation of peace-loving policies, achieved milestones and successes in all areas of the country's life, strengthening friendship with the international community, including with the diaspora of compatriots abroad.

The Committee implements measures to stimulate coordinate and promote social initiatives aimed at establishing the principles of interethnic harmony, friendship and cohesion, and developing a culture of interethnic relations. He provides practical and methodological assistance to national cultural centers, supports their initiatives, takes measures to strengthen the consciousness of citizens, regardless of their nationality, race and religious convictions, of a sense of belonging to a single large multinational family, implementation of the principle "Uzbekistan is our common home".

Particular attention is paid to educating young people in the spirit of tolerance and tolerance, respect for national and universal values, preservation and development of history, culture, national traditions and customs. It will also contribute to the formation of a harmonious and spiritually developed young generation, which has ideological immunity against the dogmas of nationalism and extremism, devoted to the ideas of independence and protection, promoting the national interests of Uzbekistan.

The Committee is entrusted with the function of representing the interests of national cultural centers and friendship societies in state bodies, coordinating their activities, assisting in the preservation and development of original national traditions, customs and rituals, and strengthening friendly, equal and mutually beneficial relations with foreign countries [6].
At a new stage in the development of Uzbekistan, stability in interethnic relations, tolerant relations between representatives of 130 nationalities become the basis for the implementation of economic, political, spiritual and cultural reforms in Uzbek society. Uzbekistan, as a country of historical tolerance and cultural pluralism, is characterized by these key properties:

- All ethnic and religious groups inhabiting Uzbekistan clearly recognize it as their homeland; full agreement, understanding and mutual respect of representatives of various national and religious groups;

- Regardless of their nationality, citizens of Uzbekistan are convinced that tolerance and interethnic harmony are one of the factors of stability and civil peace in Uzbekistan;

- the advancement of Uzbekistan to a democratic rule of law and a socially oriented market economy is directly related to the further development and harmonization of interethnic and interfaith relations, mutually beneficial partnership of the titular nation as a leader and national communities and communities, their social solidarity;

- Conditions for legal equality, economic and social freedom of all citizens, regardless of their nationality;

- the titular nation, together with other ethnic groups, constitutes a powerful potential for stimulating and accelerating the processes of formation of public consciousness, and the established interethnic relations are a guarantee of peace and stability worthy of the life of every family;

- Interethnic and interfaith harmony in Uzbekistan in close combination with the growth of national identity and spiritual revival of the Uzbek and other peoples is a powerful impetus for the renewal of society and its democratization.

It is safe to say that in Uzbekistan there is multi-ethnic democracy, that is, an independent, sovereign political system, which is characterized by democratic decision-making institutions with more than a hundred ethnic groups.

At the same time, in the context of ongoing globalization and the transformation of international and regional relations, the intensification of economic, political, national, religious and other contradictions in the world, the growing confrontation in information and cyberspace, a number of topical issues remain in the field of interethnic relations and the further development of friendly relations with foreign countries requiring their solution, including:

- a further increase in the level of interaction between state bodies and organizations, local executive bodies with civil society institutions in the field of interethnic relations and the further development of friendly relations with foreign countries; 
- establishing local systems and mechanisms for monitoring the state of interethnic relations as the basis for organizing activities for early warning and prevention of possible disagreements and conflict situations in society;

- Implementation of a set of educational, informational, cultural and educational measures to foster a culture of interethnic communication, study the history and traditions of the people of Uzbekistan;

- Improvement of work on training, retraining and advanced training of specialists of state bodies.

\section{CONCLUSION}

The historical experience of tolerance and interethnic harmony in Uzbekistan deserves attention, can be studied and used in the practical activities of other states. Meanwhile, globalization, integration, migration processes put new problems and challenges on the agenda. The main directions of the state policy of the Republic of Uzbekistan in the field of interethnic relations at the present stage is:

- improving the mechanisms of interaction between state bodies and organizations, local executive authorities with civil society institutions, including the media, in the implementation of the state policy of the Republic of Uzbekistan in the field of interethnic relations and the further development of friendly relations with foreign countries;

- the creation of additional socio-economic conditions for the effective implementation of the state policy of the Republic of Uzbekistan in the field of interethnic relations and the further development of friendly relations with foreign countries, the preservation and development of the language, culture, traditions and customs of representatives of various nations and nationalities living in the republic;

- further strengthening the feeling of a multinational large family in society, friendship and harmony between representatives of various nations and nationalities living in the republic, educating the young generation in the spirit of love and devotion to the Motherland, ensuring the equal rights of citizens, and preventing infringement of their constitutional rights and freedoms; development of international cooperation and friendly relations with foreign countries in order to strengthen international relations, protect the rights, freedoms and legitimate interests of citizens in the country and abroad, support compatriots and close cooperation with the Uzbek diasporas abroad, increase the authority and image of Uzbekistan on the world arena[7];

- Improving the legal framework of interethnic relations, taking into account the priorities of state and social development of the Republic of Uzbekistan advanced foreign experience.

\section{REFERENCES}

1. International Convention on the Elimination of All Forms of Racial Discrimination December 21, 1965 // Current international law.Volume 2. M, 1999. - P.72.

2. The Constitution of the Republic of Uzbekistan. - Tashkent, 2003; Law of the Republic of Uzbekistan "On the state language". - Tashkent, 1996; The Law of the Republic of Uzbekistan "On Citizenship". - Tashkent, 1992, etc.

3. Decree of the President of the Republic of Uzbekistan Sh. Mirziyoyev "On approval of the Concept of state policy of the Republic of Uzbekistan in the field of interethnic relations"// Lex.uz No.VII - 5876. 11/15/2019.

4. The Universal Declaration of Human Rights // Current international law. Volume 2. - M., 1999.-- P.5.

5. Decree of the President of the Republic of Uzbekistan S. Mirziyoyev "On measures to further improve interethnic relations and friendly relations with foreign countries" // Narodnoe Slovo, 2017, May 23.

6. There given.

7. Decree of the President of the Republic of Uzbekistan Sh. Mirziyoyev "On approval of the Concept of state policy of the Republic of Uzbekistan in the field of interethnic relations" lex.uz №.VII - 5876. 11/15/2019. 